Research Article

\title{
Profitability and Allocative Efficiency of Exotic Chicken Enterprises in Delta State, Nigeria
}

\section{Theophilus Miebi Gbigbi* and Rodney Akpoviri Isiorhovoja}

Department of Agricultural Economics and Extension, Faculty of Agriculture, Delta State University Asaba Campus, Asaba Nigeria.

Abstract | The purpose of this research was to estimate the resource allocation efficiency and profitability of exotic chicken enterprises in Delta State, Nigeria. A multistage sampling procedure was adopted to pick a sample of 120 farmers from whom data were elicited using structured questionnaire. Data were analyzed using descriptive and inferential statistics. The findings indicate that the average age of respondents was 43 years; majority (85\%) of respondents were males with 16 years' experience in exotic chicken production; $75 \%$ were married and $48 \%$ had secondary education. The mean household size was 5 persons. Budgetary analysis showed a net return of $\$ 930,700.00$ per annum and return on investment was 1.73 per naira. This means that exotic chicken production is profitable. The double log regression model result shows that cost of day old chicks, feed, drugs and vaccines, labour, shelter and equipment significantly influenced exotic chicken production. The resource use efficiency result infers that DOCs and drugs and vaccine were under-utilized while feeds, labour and housing and equipment were over-utilized by the farmers. The elasticity of production was 1.08 . This is increasing returns to scale. This paper concludes that poultry farmers were inefficient in the application of productive resources and recommends capacity building on resource use for farmers. We recommend that credit facilities and specific training opportunities on resource use be extended to farmers to enhance their exotic chicken production efficiency.

Received | April 23, 2021; Accepted | June 29, 2021; Published | November 30, 2021

*Correspondence | Theophilus Miebi Gbigbi, Department of Agricultural Economics and Extension, Faculty of Agriculture, Delta State University Asaba Campus, Asaba Nigeria; Email: gbigbitheophilusmiebi@yahoo.com

Citation | Gbigbi, T.M. and R.A. Isiorhovoja. 2022. Profitability and allocative efficiency of exotic chicken enterprises in Delta State, Nigeria. Sarhad Journal of Agriculture, 38(1): 128-136.

DOI | https://dx.doi.org/10.17582/journal.sja/2022/38.1.128.136

Keywords | Allocative efficiency, Exoticchicken, Farmers, Production, Profitability

\section{Introduction}

$\mathrm{E}$ xotic chicken production is outstanding in that it gives the highest turnover rate in the livestock enterprises. Finances invested in poultry production are realized sooner than from other categories of the livestock industry. Exotic chicken is well-thought-out as healthy diet, since it contains adequate amounts of protein, energy, amino acid, vitamins and minerals to satisfy the body needs given its high quality eggs and meat (Chrystal etal.,2020; Moss et al.,2018). Ayanwale et al. (2019) opined that WHO recommended daily intake of $65 \mathrm{~g}$ of protein out of which $35 \mathrm{~g}$ (38.8\%) should be from animal sources. They further stressed that Nigeria's consumption of protein is $15 \mathrm{~g}$ per head per day which is below the WHO recommendation. Inadequacy of protein intake, especially of meat and egg, lead to protein energy malnutrition (P.E.M.). 
Viewed against this background, poultry production becomes of considerable importance to both the government and the private sector.

Ferdushy et al. (2016) have long recognized the value of poultry in terms of minimizing poverty. Poultry farming is widely practiced throughout Africa. Almost every household keeps certain breeds of poultry largely for domestic consumption, cash from sales and socio-cultural use (Nduthu, 2015). Chickens are of great use in many economic, cultural and religious activities including entertainment, gifts, funeral rites and spiritual purification throughout Kenya (Ipara, 2019). Ethiopians, likewise, keep birds for domestic consumption, sale, and reproduction, as well as other social and cultural functions (Assefa, 2019).

In his research in Rwandan rural areas, Jaques (2012), endorsed the works that poultry has a significant nutritional and economic benefit in the village and also plays a vital role in society through its contribution to rural cultural and social life. The production systems include intensive, semi-intensive and extensive methods. Poultry enterprises in the Nigeria are characterized more by failures rather than success largely because farmers attempt to transfer inappropriate technology, requiring expensive and often imported inputs, instead of exploiting locally available resources (Nkukwana, 2018; Swinnen and Kuijpers, 2017). Observations show that the poultry business is inundated by risks and uncertainties such as natural risks, poultry ailments and pests and high mortality rates. This scenario would lead to economic losses on investment (Wu, 2018; Suit and Choudhary, 2015).

Several attempts have been made to introduce exotic poultry breeds into Nigeria to boost production. But the intended purpose of solving the problem of poor quality of indigenous chicken was not achieved. However, Akintunde et al. (2015), Padhi (2016) asserted that improved management and feeding practices will increase the productivity of eggs and meat of chickens in Nigeria. Unfortunately, in Delta State today, the cost of building materials necessary for intensive management of poultry is beyond the reach of the poor.

The absence of feed mills and the supply dependency in large cities and its environs on certain ingredients add to the overall feeding cost in many parts of the country. The lack of bulk supplies and storage lead to higher feed costs. Mixed feed prices remain unreasonably high even when prices of the largest component of mixed rations (for example maize) decrease by more than 50\% (Dessieet al., 2013).

Enhanced productivity is a logical procedure aimed at increasing the level of farm resources and making productive use of capital (Gbigbi, 2019). In order to achieve efficiency in exotic chicken production, resources must be optimally utilized. Performance and efficiency are global competitiveness metrics (Cechura et al., 2014). Farmers productivity in using available resources and technology is crucial to farm growth (Dessale, 2019; Sujan et al., 2017). The effective use of agricultural resources is an important element of the sustainability of agriculture (Tian et al., 2018). This is a precondition for optimal production as inefficiency in resources use can impair food access and food security (Gbigbi, 2017).

A number of researches have been conducted on efficiency generally in Nigeria (Ojo, 2003; Etim et al., 2005; Goni et al., 2013; Adenuga et al., 2013; Ayinde et al., 2011) but none of these studies addressed the profitability and allocative efficiency of exotic chicken production in Delta State. In addition, related research results are dated far back such that they bear little or no relevance to present day circumstance hence they are of hardly any meaningful value in effective policy formulation. The need to have updated information on the subsector which could serve as veritable input for policy formulation and as a reference source provide the pedestal for this study.

This study therefore seeks to fill this knowledge gap by identifying major factors retarding the productivity of the existing poultry enterprises and how farm resources use can be improved for optimum productivity. It also identified ways of increasing the level of exotic chicken production so as to reduce the supply-demand deficit in the State. The thrust of the study was to examine the profitability and allocative efficiency of exotic chicken farms in Delta State. The precise objectives are:

- To identify the socioeconomic attributes of exotic chicken farmers.

- To evaluate costs and return associated with exotic chicken production.

- To examine the production factors that affect production. 
- To determine the elasticity of production and return to scale.

- To estimate the resource allocative efficiency of exotic chicken producers.

\section{Materials and Methods}

This study was conducted in Delta State of Nigeria. A multistage sampling procedure was used to pick local government areas, communities and respondents for the study. In stage 1 , two of the three agricultural zones were selected at random. Delta North and Delta Central were the designated agricultural areas. Furthermore, in stage 2, due to the high level of involvement in poultry farming, three local government areas were chosen deliberately. Ndokwa South, Ukwuani, Aniocha North, Ughelli North, Okpe and Udu. In stage 3, two (2) communities were randomly selected from each LGA, with a total of 12 participating communities. Ten (10) poultry farmers from each community were selected on a random basis and structured questionnaires were distributed to a total of 120 respondents from the list of poultry farmers generated by the Delta agricultural and rural development authority (DARDA). Nevertheless, 20 copies of the questionnaire were discarded due to non-response and incorrect information. Thus, data for 100 respondents were used for the study.

The data collected were price of day-old chicks, cost of feeding, medication and some socio-economic variables of the poultry farmers such as gender, age, marital status, educational level, and family size.

\section{Model specification}

Costs and returns analysis: Costs and returns analysis was carried out using the budgetary technique. Indicators such as net income, profit margin percentage and return per naira invested were analyzed:

Net farm income $=T R-T C$

Profit margin \% = net income/total income ${ }^{*} 100$

Returns per naira invested $=$ Total income/total cost

$$
T C=T F C+T V C
$$

$\mathrm{TR}=$ Total revenue $; \mathrm{TC}=$ Total cost $; \mathrm{TFC}=$ Total fixed cost TVC $=$ Total variable cost.

\section{Regression model}

The regression model was employed to estimate the resource use and productivity of exotic chicken production.

The explicit form of the model as follow:

$$
\begin{aligned}
\text { TVOP } & =b_{o}+b_{1} \mathrm{DOC}+b_{2} C O F+b_{3} C O D V \\
& \left.+b_{4} L B R+b_{5} C O H E+e\right)
\end{aligned}
$$

Where;

TVOP $(Y)=$ output $(N)$ per year; DOC $=$ cost of dayold chick ( $)$; COF = cost of feed $(\mathbb{N} / \mathrm{kg})$; CODV = cost of drugs and vaccines ( $\mathrm{N} /$ litres); LBR= labour (man days); $\mathrm{COHE}=$ cost of housing and equipment (N); $b_{1}-b_{n}=$ coefficient of independent variables; $X_{1}-$ $\mathrm{X}_{\mathrm{n}}=$ vector of input quantities; $\mathrm{e}=$ stochastic error term.

\section{Resource use efficiency}

The marginal value product (MVP) of day-old chicks, feeds, medications and vaccines, labor, housing and equipment were calculated and then equated with their input prices to determine level of resources use efficiency.

Since the evaluated function expresses such variable in physical quantities, the MVP of such variable shall be matched to the price of its unit to determine its performance.

$$
\mathrm{r}=\frac{\text { Marginal value product }}{\text { Marginal factor cost }}=\frac{\text { MVP }}{\text { MFC }}
$$

Where;

$\mathrm{MVP}=$ Product of marginal physical product and unit price of output; $\mathrm{MFC}=$ Cost of one unit of a particular resource; $r=$ efficiency ratio

If there is no difference between its MVP and its MFC, a given resource is optimally allocated.

According to Gbigbi (2019), three scenarios can be observed;

(a) $M V P_{x 1} / M F C_{x 1}<1$, indicates that resource $\mathrm{X}_{1}$ is optimally utilized.

(b) $M V P_{x} / M F C_{x 1}<1$, indicates that resource $\mathrm{X}_{1}$ is over-utilized

(c) $M V P_{x 1} / M F C_{x 1}<1$, indicates that resources $\mathrm{X}_{1}$ is under-utilized.

\section{Results and Discussion}

\section{Socio-economic characteristics of respondents}

Table 1 which shows the socioeconomic characteristics of the respondents reveals that the modal age group 
is 40 to 50 years with $39 \%$ of the respondents. This is followed by age group 29-39 years with $32 \%$ of the respondents in this category. The mean age was 44 years. The result suggests that most of the respondents $(75 \%)$ are still vibrant and this could play a major role in helping the household business to grow. The finding also concurs with Gbigbi (2017) that majority of poultry producers were 42 years old.

Table 1: Socio-economic characteristics of respondents $(N=100)$.

\section{Variables}

Frequency Percentage Mean/Mode

Age category (years)

$\begin{array}{lll}18-28 & 4 & 4 \\ 29-39 & 32 & 32 \\ 40-50 & 39 & 39 \\ 51-61 & 18 & 18 \\ 62-72 & 7 & 7\end{array}$

Sex

$\begin{array}{llll}\text { Male } & 85 & 85 & \text { Male } \\ \text { Female } & 15 & 15 & \end{array}$

Marital Status

$\begin{array}{llll}\text { Single } & 9 & 9 & \\ \text { Married } & 75 & 75 & \text { Married } \\ \text { Divorced } & 6 & 6 & \\ \text { Widowed } & 10 & 10 & \end{array}$

Educational level

$\begin{array}{llll}\text { No formal education } & 29 & 29 & \\ \text { Primary education } & 17 & 17 & \text { Secondary } \\ \text { Secondary education } & 48 & 48 & \\ \text { Tertiary education } & 6 & 6 & \\ \text { Family size } & & & \\ 1-3 & 17 & 17 & 5 \text { persons } \\ 4-6 & 56 & 56 & \\ 7-9 & 24 & 24 & \\ 10-12 & 3 & 3 & \end{array}$

Farming Experience

$\begin{array}{llll}0-4 \text { years } & 2 & 2 & \\ 5-9 & 8 & 8 & \text { 16 years } \\ 10-14 & 18 & 18 & \\ 15-19 & 47 & 47 & \\ 20-24 & 25 & 25 & \\ \text { Monthly Income (N000 ) } & & \\ \text { N5,000-N10,000 } & 42 & 42 & \\ \text { N10,001-N15,000 } & 49 & 49 & \\ \text { N15,001-N20,000 } & 7 & 7 & \\ \text { N20,001-N25,000 } & 2 & 2 & \end{array}$

Source: Survey data, 2019.
On sex, $85 \%$ of the respondents were males and $15 \%$ were females. This implies that males are predominant in poultry farming. This may be due to the tedious nature of activities involved in poultry production. This is in conformity with Moussa et al. (2019) and Tsado et al. (2018) findings that majority of people involved in poultry farming were males. The majority of respondents (75\%) were married, $9 \%$ were single, $10 \%$ were widowed and the remaining $6 \%$ were divorced. Thus, majority of the respondents were married. The reason for high proportion of married people in small-scale poultry production was for economic empowerment. Mbah (2018) made a similar finding, stating that married farmers were more involved in poultry farming than unmarried farmers.

Forty eight percent (48\%) of the respondents had secondary education, $29 \%$ had no formal education and $17 \%$ and $6 \%$, respectively, had primary and tertiary education. This infers that high proportion of the respondents were literate. High literacy level facilitates understanding of issues and enhances the ability to implement modern poultry handling practices, thus increasing efficiency and profitability. It is predicted that a farmer's level of education would have a direct impact on his or her decision-making. This supports Gbigbi (2021) findings that majority of the producers were educated in the study area.

The results further show that $56 \%$ of respondents had 4-6 people in their homes. Twenty four percent (24\%) had household size of 7-9 persons and $17 \%$ had 1-3 people in their household. The remaining 3\% of respondents have a family size of more than nine. The average family size was 5 persons. This means that the small number of people in the household may reduce the rate of consumption and make the income from the poultry industry more productive. This is congruent with finding of Mbah (2018).

Experience in poultry farming could enhance the efficiency in the management of farm resources, which has direct positive effects on poultry production. The result shows that $26 \%$ of the farmers have spent between 5 and 14 years in poultry farming: Forty seven percent $(47 \%)$ of the respondents were found to have spent between 15 and 19 years in poultry farming and $25 \%$ spent above 19 years in poultry farming. The mean years of poultry farming experience was 16 years. This shows that respondents 
have a longstanding experience in poultry production and that respondents can make better decisions to improve productivity and income, since experience in poultry farming is expected to usually determine the efficiency of farmers' decision on input combinations or allocation of resources. This agrees with the findings of Suleiman et al. (2017) that poultry farmers had spent many years in the business. He had a mean of 12 years experience. Most of those interviewed (91\%) earned $\$ 5000-\$ 15000$ monthly income. Those who earned more than $\$ 20000$ per month was $2 \%$ of all respondents. The monthly average revenue was $\$ 10,950.29$ which was far lower than the national minimum monthly wage of $\$ 30,000$. This indicates that the respondents had low income which could affect their level of poultry production.

Table 2: Estimated costs and returns of exotic chicken production.

\begin{tabular}{|c|c|c|c|c|}
\hline Items & $\begin{array}{l}\text { Total } \\
\text { Quan- } \\
\text { tity }\end{array}$ & $\begin{array}{l}\text { Unit } \\
\text { Cost } \\
\text { (N) }\end{array}$ & $\begin{array}{l}\text { Total } \\
\text { Value (N) }\end{array}$ & $\begin{array}{l}\text { Per- } \\
\text { centage } \\
\text { of cost }\end{array}$ \\
\hline \multicolumn{5}{|l|}{ Variable Cost } \\
\hline - Day old chicks & 505 & 150 & 75,750 & 14.11 \\
\hline - Feeds & & & 184,000 & 34.28 \\
\hline - Labour & $\begin{array}{l}83.3 \\
\text { mandays }\end{array}$ & 1500 & 125,000 & 23.29 \\
\hline -Drugs and vaccines & & & 23,650 & 4.41 \\
\hline Total & & & 408,400 & \\
\hline \multicolumn{5}{|c|}{ Fixed Cost depreciated } \\
\hline - Housing & 2 & 22,000 & 44,000 & 8.20 \\
\hline -Poultry equipment & 32 & 450 & 14,400 & 2.68 \\
\hline Generator & & & 5,000 & 0.93 \\
\hline - Value of land & & & 65,000 & 12.13 \\
\hline Total & & & 128,400 & \\
\hline Total Cost & & & 536,800 & \\
\hline \multicolumn{5}{|l|}{ Revenue } \\
\hline - Broilers & 385 & 3500 & $1,347,500$ & \\
\hline - Eggs & $\begin{array}{l}160 \\
\text { crates }\end{array}$ & 750 & 120,000 & \\
\hline Total revenue & & & $1,467,500$ & \\
\hline Net farm income & & & 930,700 & \\
\hline Profit margin \% & & & 63.42 & \\
\hline $\begin{array}{l}\text { Return per naira in- } \\
\text { vested }\end{array}$ & & & 1.73 & \\
\hline Gross margin & & & $1,059,100$ & \\
\hline
\end{tabular}

Source: Survey data, 2019.

Gross margin and net return analysis

The costs and returns analysis as shown in Table 2 revealed that the total cost incurred in exotic chicken production was $\$ 536,800.00$ while the total revenue realized was $\$ 1,467,500.00$. This gives a net return of $\$ 930,700.00$ for the poultry farmers. Cost of feed (34.28\%) constituted the highest percentage of cost followed by labour (23.29\%) and cost of day old chicks (14.11\%), respectively. The least cost element in exotic chicken production was rent on generator $(0.93 \%)$. The profit margin was $63.42 \%$ of exotic chicken production and the return on per naira invested was $¥ 1.73$. This means that the farmers made a profit of $73 \mathrm{k}$ for every 11.00 spent on the enterprise. In other words, exotic chicken production is a profitable business. This finding corroborates those of several researchers (Suleiman et al., 2017; Gbigbi, 2021) who concluded that poultry business was highly profitable.

Regression result on production efficiency of exotic chicken The result of double-log function indicates that the coefficient of multiple determinations $\left(\mathrm{R}^{2}\right)$ is 0.790 . This implies that $79 \%$ of the total variation in the output of poultry enterprise as practiced by the farmers is explained by variation in the independent variables included in the model (Table 3 ). The variable day-old chicks (DOCs) had a positive and significant relationship with the output. The positive DOC coefficient which indicates that a $10 \%$ increase in the quantity of poultry production will result in $3.25 \%$ increase in DOC. The cost of feed was positive and significant at $1 \%$, which means that an increase in feed supplies to birds would significantly increase their output. The result confirms Olorunwa (2018) finding that feeds is a major determinant of broiler production in Nigeria. The cost-effectiveness of drugs and vaccines administered to birds is positive and significant at 5\%. This indicates that an improvement in the quantity of prescribed medications and vaccines would lead to $2.56 \%$ increase in production. The result is consistent with Etuah et al. (2020) and Osuji (2019) who in their respective studies on poultry efficiency studies there found a positive and significant relationship between medication and output. The coefficient of labour had positive and significant relationship with output at $5 \%$. This means that an increase in workforce will lead to $2.37 \%$ increase in output. This conforms to the $a$ priori expectation. The more people work on a farm, all things being equal, the more care the birds receive, resulting in higher incomes. This is in tandem with the result of Kadiri (2019) findings that labour constitutes a key issue influencing output in poultry production. The regression coefficients of housing 
and equipment as independent variables were positive and significant at $5 \%$ probability level. This indicates that the provision of better infrastructure for the poultry farms will result to higher output. This is in consonance with Naseem and King (2018), that the better the provision of housing and logistics, the quicker the return for the poultry farmer.

Table 3: Regression analysis result onproduction efficiency of exotic chicken.

\begin{tabular}{llll} 
Variable & $\begin{array}{l}\text { Unstand- } \\
\text { ardized } \\
\text { Coefficients }\end{array}$ & $\begin{array}{l}\text { T } \\
\text { value }\end{array}$ & $\begin{array}{l}\text { Signifi- } \\
\text { cance }\end{array}$ \\
Cost of day old chick $\left(\mathrm{X}_{1}\right)$ & 0.325 & 3.652 & $0.002^{* * *}$ \\
Cost of feeds $\left(\mathrm{X}_{2}\right)$ & 0.130 & 4.072 & $0.002^{* * *}$ \\
Cost of drugs and vaccines $\left(\mathrm{X}_{3}\right)$ & 0.256 & 3.041 & $0.007^{* *}$ \\
Labour $\left(\mathrm{X}_{4}\right)$ & 0.237 & 2.972 & $0.006^{* *}$ \\
Cost of housing and equipment & 0.130 & 2.345 & $0.021^{* *}$ \\
$\left(\mathrm{X}_{5}\right)$ & & & \\
Constant & 14.460 & 17.602 & $0.000^{* * *}$ \\
R-Square & 0.790 & & \\
F-value & 19.256 & & \\
\hline
\end{tabular}

Source: Survey data, 2019*** Significant at 1\% level, ** significant at $5 \%$ level.

Table 4: Elasticity of production and return to scale.

$\begin{array}{ll}\text { Variable } & \text { Elasticities } \\ \text { Cost of day old chick }\left(\mathrm{X}_{1}\right) & 0.325 \\ \text { Cost of feeds }\left(\mathrm{X}_{2}\right) & 0.130 \\ \text { Cost of drugs and vaccines }\left(\mathrm{X}_{3}\right) & 0.256 \\ \text { Labour }\left(\mathrm{X}_{4}\right) & 0.237 \\ \text { Cost of housing and equipment }\left(\mathrm{X}_{5}\right) & 0.130 \\ \text { RTS } & 1.08\end{array}$

Source: Survey data, 2019.

Return to scale (RTS)

The result as indicated by the regression coefficients or b-values which measure the elasticity of response of each independent variable to output showed that one percent increase in cost of day old chick, cost of feed, cost of drugs and vaccine, labour and cost of housing and equipment would bring about 33\%, 13\%, 26\%, $24 \%$ and $13 \%$ increase in output respectively. The sum of these elasticities of production is 1.08 . This is more than unity thus indicating increasing return to scale (Table 4).

\section{Allocative efficiency estimates}

The results of the estimates of allocative efficiency in exotic chicken production are shown in Table 5. The allocative efficiency estimates of poultry resources for day old chicks, feed, drugs and vaccines, labour, housing and equipment were 5.76, 0.01, 1.54, 0.02 and 0.08 , respectively. The result shows that DOC, drugs and vaccines were underutilized and other resources have been over used which means that the allocation of poultry resources is under optimal. The underutilization of the DOC and of drugs and vaccines in the production process was caused by a lack of funding and the lack of access to loan facilities by many farmers. Feed was also over-utilized. The use of home-mixed food with a relatively low nutritional value by most farmers surveyed exacerbates this problem. The results showed that labour and housing and equipment in poultry production were overused. Excess family labour supply results in a propensity to overexploit farm labour. This condition is attributed to the gross inefficiency and over-use of labour found in the study. Therefore, inputs such as feed, labour, housing and equipment, may have to be reduced, while more land should be used, so as to achieve the optimal allocation of productive resources for poultry farmers. This is in agreement with the finding of Sanusi et al. (2019). This will increase productivity and ultimately net returns for poultry farmers in addition to the improved management skills and the acquisition of economically viable exotic breeds.

Table 5: Allocative efficiency of resources utilized in exotic chicken production.

$\begin{array}{llllll}\text { Variable } & \begin{array}{l}\text { Marginal } \\ \text { physical product } \\ \text { (MPP) }\end{array} & \begin{array}{l}\text { Marginal } \\ \text { Value Product } \\ \text { (MVP) }\end{array} & \begin{array}{l}\text { Marginal } \\ \text { Factors Cost } \\ \text { (MFC) }\end{array} & \begin{array}{l}\text { Allocative } \\ \text { Efficiency }\end{array} & \text { Remark } \\ \text { Day old chicks }\left(\mathrm{X}_{1}\right) & 7.57 & 3,420.80 & 593.54 & 5.76 & \text { Under-utilization } \\ \text { Feeds }\left(\mathrm{X}_{2}\right) & 0.5504 & 0.1801 & 33.5 & 0.01 & \text { Over utilization } \\ \text { Drugs and vaccines }\left(\mathrm{X}_{3}\right) & 0.0823 & 2.14 & 1.39 & 1.54 & \text { Under utilization } \\ \text { Labour }\left(\mathrm{X}_{4}\right) & 0.1067 & 5.46 & 2.40 & 0.02 & \text { Over utilization } \\ \text { Housing and equipment }\left(\mathrm{X}_{5}\right) & 0.0638 & 0.6 & 7.84 & 0.08 & \text { Over utilization }\end{array}$

Source: Survey data, 2019. 
Exotic chicken production attracts a relatively higher cost compared to the traditional chicken which is maintained by almost every household in Delta State, however the attendant benefits far outweigh the costs. This is the bottom line measure of any economic activity. The positive bottom line result is predicated on the increased resource use efficiency it bestows on the subsector, a key objective of every economic activity. Exotic chicken production and resource allocation and resource use efficiency are global objectives the realization of which exotic chicken production facilitates in the subsector. The teething challenges encountered presently should therefore be viewed as indicators of greater success which will accompany the full development of the subsector when the challenges have been overcome, hence we recommend that every necessary support by way of policy support especially such as facilitates the production and supply of exotic poultry inputs and credit needs of farmers, should be given to the farmers to enable the subsector reach its full potential. Similarly, necessary training on input utilization for the farmers will also be required both to stimulate their participation in exotic chicken production and efficiency in resource use.

\section{Acknowledgements}

The corresponding author of this article is grateful to the anonymous reviewers for their constructive comments that significantlyenhanced the quality of the paper.

\section{Novelty Statement}

The current study is one of the few studies which empirically investigated the profitability and allocative efficiency of exotic chicken in Delta State.

\section{Author's Contribution}

Theophilus Miebi Gbigbi: Designed the research plan and data analysis for this study and prepared the first draft of the manuscript.

Rodney Akpoviri Isiorhovoja: Assisted in reviewing the manuscript and helped in overall improvement of the final draft of the manuscript.

\section{Conflict of interest}

The authors have declared no conflict of interest.

\section{References}

Adenuga, A.H., A. Muhammad-Lawal and O.A. Rotimi. 2013. Economics and technical efficiency of dry season tomato production in selected areas in Kwara state, Nigeria. Agris Online Pap. Econ. Inf., 5(1): 11-19.

Akintunde, O.K., A.I. Adeoti, V.O. Okoruna, B.T. Omonona and A.O. Abu. 2015. Effect of disease management on profitability of chicken egg production in Southwest Nigeria. Asian J. Poult. Sci., 9(1): 1-18. https://doi.org/10.3923/ ajpsaj.2015.1.18

Assefa, H. 2019. The role of poultry for poor livelihoods in Ethiopia. Int. J. Vet. Sci. Anim. Husb., 4(3): 1-4.

Ayanwale, A.B., A.O. Funmilola, A.C. Abiodun, O.P. Mathew, A.N. Alaba and D.J. Oyedele. 2019. Food security implications of protein demand of underutilised indigenous vegetables farming households in South western Nigeria. J. Food Secur., 7(5): 183-191.

Ayinde, I.A., D. Akerele and O.T. Ojeniyi. 2011. Resource use efficiency and profitability of fluted pumpkin production under tropical conditions. Int. J. Veg. Sci., 17(1): 75-82. https://doi. org/10.1080/19315260.2010.514979

Cechura, L., H. Heinrich, M. Zdenka and M. Michal. 2014. Productivity and efficiency differences between Czech and Slovak milk producers. Rev. Agric. Appl. Econ., XVII (2): 17-21. https://doi.org/10.15414/raae.2014.17.02.1721

Chrystal, P.V., A.F. Moss A. Khoddami, V.D. Naranjo,P.H.Selle and S.Y.Liu.2020. Effects of reduced crude protein levels, dietary electrolyte balance, and energy density on the performance of broiler chickens offered maize-based diets with evaluations of starch, protein, and amino acid metabolism. Poult. Sci., 99(3):1421-1431. https://doi.org/10.1016/j.psj.2019.10.060

Dessale, M., 2019. Analysis of technical efficiency of small holder wheat-growing farmers of Jamma district, Ethiopia. Agric. Food Secur., 8: 1-8. https://doi.org/10.1186/s40066-018-0250-9

Dessie, T.W., L.V. Esatu, F. Waaij, S. Zegeye, Gizaw, O. Mwai and J. van Arendonk. 2013. Village chicken production in the central and western highlands of Ethiopia: Characteristics and strategies for improvement. Int. Livest. Res. Inst., Nairobi, Kenya, ISBN-13: 
9789291463411.

Etim, N.A., E.J. Udoh and T.T. Awoyemi. 2005. Measuring technical efficiency of urban farms in Uyo Metropolis. Glob. J. Agric. Sci., 4: 19-95. https://doi.org/10.4314/gjass.v4i1.2248

Etuah, S., K. Ohene-Yankyera, Z. Liu, J.O. Mensah and L. Jang. 2020. Determinants of cost inefficiency in poultry production: evidence from small-scale broiler farms in the Ashanti Region of Ghana. Trop. Anim. Health Prod., 52: 1149-1159. https://doi.org/10.1007/s11250019-02115-6

Ferdushy, T., M.T. Hasan, A.K.M.G. Kadir and J.P. Dis. 2016. Cross sectional epidemiological investigation on the prevalence of gastrointestinal helminths in free range chickens in Narsingdi district, Bangladesh. J. Parasit. Dis., 40(3): 818-822. https://doi.org/10.1007/s12639-0140585-5

Gbigbi, T.M. 2017. Measurement of profit efficiency among broiler producers in Delta State, $\mathrm{Ni}-$ geria. J. Agric. Technol. Environ., 6(2): 64-74.

Gbigbi, T.M. 2019. Resource use efficiency and misery of sweet potato production window into financial surplus for households in Delta State Nigeria. Int. J. Agric. Sci. Res. Technol. Ext. Educ. Syst., 9(2): 83-89.

Gbigbi, T.M. 2021. Financial benefits analysis of broiler chicken farm operators in Delta State, Nigeria. Black Sea J. Agric., 4(2): 58-65. https:// doi.org/10.47115/bsagriculture.752924

Goni, M., A.S.S. Umar and S. Usman. 2013. Analysis of resource-use efficiency in dry season vegetable production in Jere, Borno State, Nigeria. J. Biol. Agric. Healthc., 3(19): 18-23.

Ipara, B.O. 2019. An analysis of farmers and traders awareness, perception and effect of chicken value chain practices on Newcastle disease outbreaks in Kenya. An M.Sc thesis submitted to the department of Agricultural Economics, university of Nairobi.

Jacques, B.S.J. 2012. Contribution of poultry farming in socio-economic development of Rwandan rural areas. Kigali, Rwanda: National University of Rwanda.

Kadiri, B.B., 2019. Technical efficiency of family poultry production in Ondo State, Nigeria. An M. Tech thesis submitted to the department of Agricultural and Resource Economics. The Federal University of Technology, Akure, Nigeria.
Mbah, E. 2018. Investigating constraints to poultry management practices among smallholder farmers in Benue State, Nigeria. Int. J. Sustain. Agric. Res., 5(2): 27-37. https://doi. org/10.18488/journal.70.2018.52.27.37

Moss, A.F., C.J. Sydenham, A. Khoddami, V.D. Naranjo, S.Y. Liu and P.H. Selle. 2018. Dietary starch influences growth performance, nutrient utilization and digestive dynamics of protein and amino acids in broiler chickens offered low-protein diets. Anim. Feed Sci. Technol., 237: 55-67. https://doi.org/10.1016/j.anifeedsci.2018.01.001

Moussa, H.O., T.C. Keambou, K. Hima, S. Issa, S.J. Motsaa and Y. Bakasso. 2019. Indigenous chicken production in Niger. Vet. Anim. Sci., 7: 100040. https://www.sciencedirect.com/science/article/pii/S2451943X18301418 https:// doi.org/10.1016/j.vas.2018.11.001

Naseem, S. and A.J. King. 2018. Ammonia production in poultry houses can affect health of humans, birds, and the environment techniques for its reduction during poultry production. Environ. Sci. Pollut. Res. 25: 15269-15293. https:// doi.org/10.1007/s11356-018-2018-y

Nduthu, P.W. 2015. Social-economics influence on indigenous poultry production project in Kenya. A case of Machakos indigwazenous poultry. Int. J. Educ. Res., 3(1) January 2015.

Nkukwana, T.T. 2018. Global poultry production: Current impact and future outlook on the South African poultry industry. S. Afr. J. Anim. Sci., 48(5): 869-884. https://doi.org/10.4314/ sajas.v48i5.7

Ojo, S.O. 2003. Productivity and technical efficiency of poultry egg production in Nigeria. Int. J. Poult. Sci., 2(6): 459-464. https://doi. org/10.3923/ijps.2003.459.464

Olorunwa, O.J. 2018. Economic analysis of broiler production in Lagos State poultry estate, Nigeria. J. Invest. Manage., 7(1): 35-44. https://doi. org/10.11648/j.jim.20180701.15

Osuji, M.N. 2019. Assessment of factors affecting poultry (broiler) production in Imo State, $\mathrm{Ni}$ geria. Asian J. Agric. Ext. Econ. Sociol., 35(2): 1-6. $\quad$ https://doi.org/10.9734/ajaees/2019/ v35i230216

Padhi, M.K. 2016. Importance of indigenous breeds of chicken for rural economy and their improvements for higher production performance, Scientifica, vol. 2016, Article ID 2604685, 9 pages. 
https://doi.org/10.1155/2016/2604685

Sanusi, S.M., S.I. Paul, A.M. Muhammad and L. Muhammad. 2019. Total factor productivity (TFP) of productive resources used in homestead poultry broiler farms in Niger State of Nigeria. J. Agric. Sci., Belgrade 64(1): 101-119. https://doi.org/10.2298/JAS1901101S

Suit, K.C. and V. Choudhary. 2015. Mozambique agricultural sector risk assessment: Risk prioritization. Agriculture global practice technical assistance paper. World Bank, Washington, DC. (C) World Bank. https://openknowledge. worldbank.org/handle/10986/22748 License: CC BY 3.0 IGO

Sujan, M.H.K., F. Islam, M.J. Azad and S.J. Rayhan. 2017. Financial profitability and resource use efficiency of boro rice cultivation in some selected area of Bangladesh. Afr. J. Agric. Res., 12(29): 2404-2411. https://doi.org/10.5897/ AJAR2017.12443

Suleiman, R., A.M. Mahmud, Y.U. Oladimeji, T.O. Olanrewaju and O.A. Ojeleye. 2017. Effects of socio-economic characteristics on the profitability of poultry production among poultry farmers in Kaduna State. Proceedings of the $22^{\text {nd }}$ Annual Conference of the Agricultural Extension Society of Nigeria held at University of Port Harcourt, River State, Nigeria on $23^{\text {rd }}$ $-26^{\text {th }}$ April, 2017.

Swinnen, J. and R. Kuijpers. 2017. Value chain innovations for technology transfer in developing and emerging economies: Conceptual issues, typology, and policy implications. Food Policy, 83: 298-309. https://doi.org/10.1016/j.foodpol.2017.07.013

Tian, H., C. Lu, S. Pan, J. Yang, R. Miao, W. Ren, Q. Yu, B. Fu, F. Jin, Y. Lu, J. Melillo, Z. Ouyang, C. Palm and J. Reilly. 2018. Optimizing resource use efficiencies in the food energy water nexus for sustainable agriculture: from conceptual model to decision support system. Curr. Opin. Environ. Sustain., 33: 104-113. https:// doi.org/10.1016/j.cosust.2018.04.003

Tsado, J.H., I.S. Tyabo, Y. Muhammed, P. Fatoki and M. Rilwan. 2018. Knowledge Level and Poultry Farmers' Perception on Poultry Management Practices in Niger State, Nigeria. Niger. J. Agric. Ext., 19(1): 32-39.

$\mathrm{Wu}, \mathrm{T}$. 2018. The socioeconomic and ecological drivers of avian influenza risks in china and at the international level. A PhD degree submitted to Arizona State University. https://core. ac.uk/download/pdf/158457099.pdf. 